\title{
The influence of supplier integration and lean practices adoption on operational performance
}

\section{A influência da integração do fornecedor e da adoção de práticas lean no desempenho operacional}

\author{
Graziela dos Santos Bento ${ }^{1}$ (1), Klaus Siegmar Schuldt ${ }^{1}$, Luciano Castro de Carvalho ${ }^{1}$ \\ ${ }^{1}$ Universidade Regional de Blumenau - FURB, Centro de Ciências Sociais e Aplicadas, Programa de \\ Pós-graduação em Administração, Blumenau, SC, Brasil. E-mail: gsbento80@gmail.com; klaus.bnu@ig.com.br; \\ luccar@gmail.com
}

How to cite: Bento, G. S., Schuldt, K. S., \& Carvalho, L. C. (2020). The influence of supplier integration and lean practices adoption on operational performance. Gestão \& Produção, 27(1), e3339.

https://doi.org/10.1590/0104-530X3339-20

\begin{abstract}
This study investigates the influence of supplier integration and lean practices on operational performance indicators: cost, quality, delivery, flexibility and speed of new products introduction. The proposed relationships are analyzed using survey data from a sample of 112 medium-sized textile companies in Brazil. The results suggest that supplier integration is significantly and positively associated with the speed of new products introduction, while lean practices are significantly and positively associated with operational performance indicators, except delivery. In addition, supplier integration does not support lean practices for any of operational performance indicators tested.
\end{abstract}

Keywords: Supplier integration; Lean practices; Operational performance.

Resumo: Este estudo investiga a influência da integração de fornecedores e práticas enxutas nos indicadores de desempenho operacional: custo, qualidade, entrega, flexibilidade e velocidade de introdução de novos produtos. As relações propostas são analisadas a partir de dados de pesquisas de uma amostra de 112 empresas têxteis de médio porte no Brasil. Os resultados sugerem que a integração de fornecedores é significativa e positivamente associada à velocidade de introdução de novos produtos, enquanto as práticas enxutas estão significativamente e positivamente associadas a indicadores de desempenho operacional, exceto a entrega. Além disso, a integração de fornecedores não suporta práticas enxutas para nenhum dos indicadores de desempenho operacional testados.

Palavras-chave: Integração de fornecedores; Práticas enxutas; Desempenho operacional.

\section{Introduction}

Product development can be defined as the process of transformation of a market opportunity into a product available for sale (Krishnan \& Ulrich, 2001). It is an essential process for firms in either fast-paced or competitive markets (Brown \& Eisenhardt, 1995). The adoption of product development and production processes that eliminate

Received Sept. 16, 2016 - Accepted Aug. 2, 2018

Financial support: This study was financed by the Foundation for Research and Innovation Support of Santa Catarina State FAPESC under grant 03/2017.

This is an Open Access article distributed under the terms of the Creative Commons Attribution License, which permits unrestricted use, distribution, and reproduction in any medium, provided the original work is properly cited. 
waste and make the flows more agile can optimize internal resources and help organizations with faster introduction of products and reduced costs.

One way of reducing waste is the implementation of Lean practices, also known as lean production or TPS (Toyota Production System). Lean philosophy is a multidimensional approach that integrates practices like just-in-time, quality systems, work teams, manufacturing cells and supplier management (Shah \& Ward, 2003). In this system, making parts according to specifications it is not enough. Suppliers are extensions of their technical capabilities, thus, they are expected to innovate and work closely with the customer throughout the product development process (Liker \& Meier, 2007).

Jasti \& Kodali (2015) identified that supplier involvement is the most popular Lean practice in a cross-sectional exploratory study. While the adoption of lean practices and supplier involvement in product development are considered relevant to most organizations, the existing studies were based on large and high-tech organizations such as the automotive, electronics and machinery industry. Previous research related to suppliers integration in the product development process found divergent results when analyzing their influence on operational performance. While some authors found a positive influence of supplier integration on operational performance (Devaraj et al., 2007; Armistead \& Mapes, 1993; Handfield et al., 1999), others did not identify evidence of a direct relationship (Swink et al., 2007; Flynn et al., 2010). In the case of lean manufacturing, studies found a direct relationship between lean practices and operational performance (Womack et al.,1990; De Toni \& Nassimbeni, 2000; Rahman et al., 2010; Khanchanapong et al., 2014).

This study seeks to verify the influence of supplier integration and the adoption of lean practices on operational performance of new products. To elucidate the proposed discussion, we investigated medium-sized companies and low-tech industries, such as the textile industry. The textile industry was chosen for study purposes due to the dynamics of the market in which it is inserted. At least four product development processes are started annually, obeying the seasonality of their products. Additionally, this industry launches products with short cycle and rapid obsolescence, which reinforces the idea of reformulation and development of new products. A quantitative approach with a causal study was used to reach the objective of this research. In this context, we tried to test the causal relationships between supplier's integration and adoption of Lean practices, as well as their influence on operational performance.

\section{Literature review}

In this topic, definitions and results of previous studies that support the proposal of this study are elucidated. In this way, studies that deal with supplier's integration in the process of product development, adoption of lean practices and operational performance are reviewed.

\subsection{Supplier integration in New Products Development process}

Supply chain integration is the degree to which a manufacturer collaborates strategically with its chain partners and collaboratively manages organizational processes to achieve effective flows of products and services, information, revenue and decisions to provide value to the customer (Flynn et al., 2010). The integration 
process involves the degree of responsibility for the project, the decision of how and when to involve suppliers in the process, communication between firms, intellectual property agreements, inclusion of suppliers in the project team, and alignment of organizational goals related to the expected results. (Handfield et al., 1999).

The involvement of material suppliers in the new product development cycle can provide substantial benefits for reaching company's targets. This involvement can range from consulting with suppliers on design ideas, to making suppliers fully responsible for designing the components or systems they will provide. In addition, suppliers may be involved in different stages of the new product development process. Early supplier involvement is a key coordination process in supply chain design, product design, and process design. (Petersen et al., 2005).

Understanding the importance of supplier integration in the product development phase, it is important to comprehend what product development is. Krishnan \& Ulrich (2001) define product development as the transformation of a market opportunity into an available-for-sale product. For Brown \& Eisenhardt (1995), it is one of the essential processes for the success, survival, and renewal of organizations, especially for fast-paced organizations or competitive markets. On a rational level, the development of a successful product is the result of careful planning of a superior product for an attractive market and execution of the plan by a competent and well-coordinated multifunctional team operating with the support of senior management (Brown \& Eisenhardt, 1995).

Cooper \& Kleinschmidt (1986) explain the following activities to the process of new products:

a) Initial Screening - The initial go/no go decision where it was first decided to allocate funds to the proposed new product idea;

b) Preliminary market assessment;

c) Preliminary technical assessment;

d) Detailed market study/market research;

e) Business/financial analysis;

f) Product development;

g) In-house product testing;

h) Customer tests of product;

i) Test market/trial sell;

j) Trial production;

k) Precommercialization business analysis;

I) Production start-up;

m) Market launch.

Involving suppliers in product development projects can help to reduce costs, reduce lead time from concept to customer, improve quality, and create innovative technologies that can help to capture market share (Handfield et al., 1999).

Another contribution to the product design process is the involvement of suppliers in product design teams, providing inputs about the performance of prospective materials and parts (Khanchanapong et al., 2014). For Handfield et al. (1999), one of the most important activities in the new development process is to explore the focal suppliers' competences and expertise to conduce a technology risk assessment. This is in line with Watts \& Hahn (1993), who proposed that supplier development efforts should focus on developing future capabilities in technology and product development 
providers, rather than current quality and cost. They insist that developing supplier capacity and flexibility would be the key to supplier development success. Petersen et al. (2005) reinforce the criticality of the supplier selection decision, that must considerate both supplier's capabilities and culture, which will impact the buyer's ability to effectively interact with the supplier.

Another benefit of supplier integration is described by Dyer (1996): specific investments in relationships could make suppliers more willing to make customized articles for customers. Moreover, better relationships would allow both parties to communicate more efficiently, resulting in shorter product development cycles and lower acquisition costs. Involving the supplier in determining metrics and goals for the project and reaching consensus on those goals is a key element in the effectiveness of the project team. This is particularly important in situations where the supplier will receive a high level of responsibility in the design process (Petersen et al., 2005).

In this sense, involvement in design activities is usually accompanied by an intense exchange of product information (materials and components to be supplied, engineering / industrialization choices, etc.) and engineering and process (production cycles and tools, process, etc.). This involves the simplification and modularization of the product, standardization of the components, the choice of materials, processes and production cycles (De Toni \& Nassimbeni, 2000). Suppliers who participate from the outset of the product development process can offer a more cost-effective design option, help select the best components and technologies, and assist with design assessment (Monczka et al., 1993).

A study by Pérez \& Sánchez (2000) with 28 participants from automotive suppliers in the Spanish region of Aragón shows that almost half of the companies cooperate with customers, suppliers and technological centers, to improve their production processes. However, the study indicated low involvement of surveyed companies with their customers in the development of components and design. Handfield et al. (1999) point out that although the results of their research point to significant improvements for companies that involved suppliers in their projects, only $20 \%$ of respondents said they were satisfied with the results of their integration efforts with suppliers. The results of both studies demonstrate that many companies realize the importance of supplier integration but have not yet figured out how to successfully complete it. Collaborative practices and efforts such as green procurement built into supplier exchanges between suppliers, suppliers and customers, with cross-functional co-operation to achieve maximum long-term benefits are also important from an environmental and sustainable perspective (Feng et al., 2018).

\subsection{Lean practices}

Lean philosophy, also known as lean production or STP (Toyota Production System), is a multidimensional approach that encompasses a wide variety of management practices, including just-in-time, quality systems, work teams, manufacturing cells, supplier management, etc., in an integrated system (Shah \& Ward, 2003). It is an integrated system to produce goods/ services with the least damping costs (Hopp \& Spearman, 2004). It is a manufacturing system that includes waste disposal practices characterized by reduced set-up time, reduced batch size and pulled production (Li et al., 2005).

Lean is considered "lean" because it uses less resources compared to mass production: half human effort, half the space, half the investment in tools, half the engineering hours to develop a new product in half the time (Womack et al., 1990). 
Product development is seen as a process that can be standardized and refined to eliminate wastage and continuously reduce lead time and cost (Liker \& Morgan, 2006). In order to bring results, lean management principles must extend beyond the shop floor, easily found in all processes in the board room, in the sales offices, and very clearly in the product development process (Liker \& Morgan, 2006).

One of the critical lean implementation factors is the simultaneous adoption of lean practices in the supply chain (Bhamu \& Singh Sangwan, 2014). Supplier involvement in product/ process development has become an essential element among the set of lean purchasing practices available. Consulting and technical assistance from the supplier can generate parts with improved design, achieve lower costs and higher quality and productivity. These benefits can be summarized as follows: reduced development costs (initial availability of prototypes, consistency between design and supplier capabilities, reduced engineering changes), improved product quality, reduced overall development time (identification of technical problems of the supplier at the beginning), possibility of incorporating innovations suggested by the supplier (De Toni \& Nassimbeni, 2000). However, Bhamu \& Singh Sangwan (2014) have identified that poor logistics, supplier integration, frequent changes in customer demand and volatile demand are some of the challenges to be overcome in implementing lean supply chain management concepts.

\subsection{Operacional performance}

The most commonly used indicators for measuring operational performance include costs, quality, delivery and flexibility. Subsequently, the rate of introduction of new products and speed of introduction of new products were included in the list of indicators (Ahmad \& Schroeder, 2003).

There is increasing empirical evidence that higher levels of integration along the supply chain are associated with large potential benefits. The results of the Armistead \& Mapes (1993) study indicate that increasing the level of integration increases operational performance in quality, cost, delivery speed and flexibility. The results of the studies by Swink et al. (2007), indicate that the integration of suppliers is negatively associated with the capacity to produce with quality when compared to the competition. The argument for this assertion is that the knowledge gained through interaction with suppliers can be replicated by the competition that has access to the same suppliers. Flynn et al. (2010) and found evidence that the integration of suppliers is not directly related to operational performance, when analyzed in isolation. The authors suggest that supplier integration should be analyzed in conjunction with customer integration and internal integration so that there is influence on operational performance. Feng et al. (2018) found that environmental and operational performance has a mediating role in the financial performance of Chinese automobile manufacturers. Green practices in supply chain management are significantly and positively associated with environmental and operational performance, which indirectly leads to better financial performance. Thomé et al. (2014a) studied 725 companies from different manufacturing and assembling industries in 34 countries to examine the impact of sales and operations planning (S\&OP) practices on manufacturing operational performance. The practice of supply chain integration did not have a significant impact on operational performance. However, supplier integration moderated positively the relationship between internal S\&OP and performance, suggesting that companies with more mature supplier integration amplify the effect of internal S\&OP on operational performance. Thomé et al. (2014b) also investigated whether S\&OP practices such as 
organizational management, technological integration, measurement systems and integration of plans influence operational performance. The results showed that these practices positively influence quality, reliability and flexibility.

Regarding the adoption of lean practices, the research conducted by Khanchanapong et al. (2014) demonstrates the importance of manufacturing technologies and lean practices in forecasting manufacturing operational performance. Both are associated with the four dimensions of operational performance: cost, quality, reliability and flexibility, suggesting that they are valuable resources to achieve operational advantages. Rahman et al. (2010) have identified in a study conducted in companies in Thailand that lean dimensions such as just-in-time, waste reduction and flow management are significantly related to operational performance. Inman \& Green (2018) have identified that lean practices with suppliers and customers aimed at eliminating all forms of waste from all supply chain processes positively impact operational performance. Belekoukias et al. (2014) found that JIT is the lean practice with the greatest impact on improving operational performance indicators such as quality, reliability, cost, speed and flexibility. Proximity to suppliers is one of the characteristics of JIT that helps organizations improve reliability.

In this context, we attempted to test the causal relationships between supplier integration and adoption of Lean practices, as well as their influence on operational performance, as shown in Figure 1.

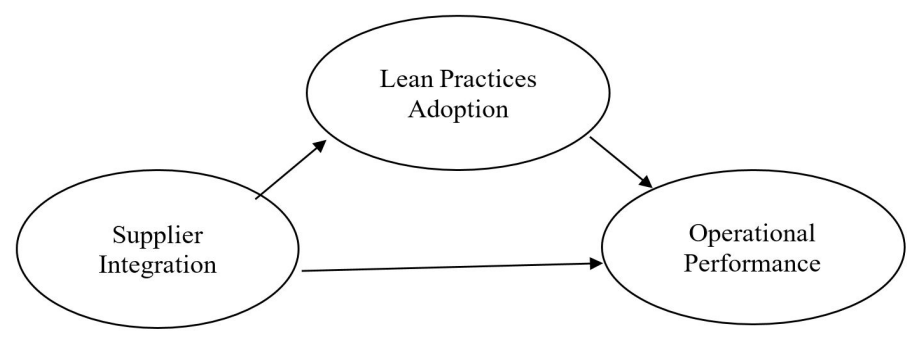

Figure 1. Conceptual Model.

\section{Metodology}

To estimate the relationships between supplier integration, lean manufacturing practices and operational performance, a quantitative approach was adopted, using Structural Equation Modeling, which simultaneously provides the relationships between the variables. The stages of research development can be seen in Figure 2.

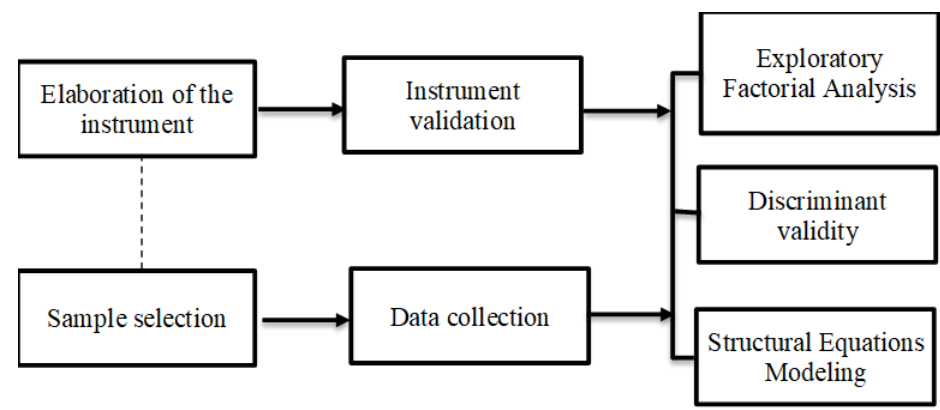

Figure 2. Stages of research development. 
The data collection instrument was constructed based on already validated dimensions in international contexts, in an online platform. Because they were translated into the Portuguese language and adapted to the purpose of this study, the dimensions were statistically revalidated. The items of the dimensions have five-point Likert-type staggered response options, where 1 indicates total disagreement and 5 indicates total agreement with the item's affirmative. The questions that make up the questionnaire are presented in Table 1.

Table 1. Instrument.

\begin{tabular}{|c|c|c|c|}
\hline Dimension & Code & Items & Ref. \\
\hline \multirow{6}{*}{ 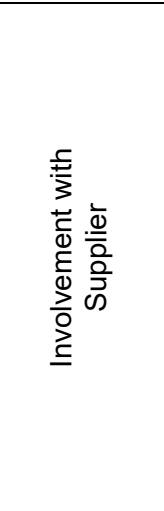 } & SUPP01 & $\begin{array}{l}\text { We involve key suppliers in the product design and } \\
\text { development stage. }\end{array}$ & \multirow{6}{*}{$\begin{array}{l}\text { Chen \& } \\
\text { Paulraj } \\
(2004)\end{array}$} \\
\hline & SUPP02 & $\begin{array}{l}\text { We have key supplier membership/participation in } \\
\text { our project teams. }\end{array}$ & \\
\hline & SUPP03 & $\begin{array}{l}\text { Our key suppliers have major influence on the } \\
\text { design of new products. }\end{array}$ & \\
\hline & SUPP04 & $\begin{array}{l}\text { There is a strong consensus in our firm that } \\
\text { supplier involvement is needed in product } \\
\text { design/development. }\end{array}$ & \\
\hline & SUPP05 & $\begin{array}{l}\text { We involve our key suppliers in business and } \\
\text { strategy planning. }\end{array}$ & \\
\hline & SUPP06 & $\begin{array}{l}\text { We have joint planning committees/task forces on } \\
\text { key issues with key suppliers }\end{array}$ & \\
\hline \multirow{5}{*}{ 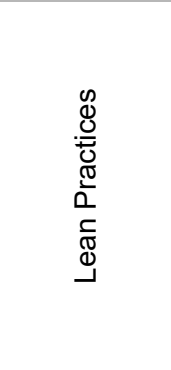 } & LEAN01 & $\begin{array}{l}\text { Our firm has continuous quality improvement } \\
\text { program }\end{array}$ & \multirow{5}{*}{$\begin{array}{l}\text { Li et al. } \\
(2005)\end{array}$} \\
\hline & LEAN02 & Our firm pushes suppliers for shorter lead-times & \\
\hline & LEAN03 & Our firm reduces set-up time & \\
\hline & LEAN04 & Our firm uses a "Pull" production system & \\
\hline & LEAN05 & $\begin{array}{l}\text { Our firm streamlines ordering, receiving and other } \\
\text { paperwork from suppliers }\end{array}$ & \\
\hline \multirow{5}{*}{ 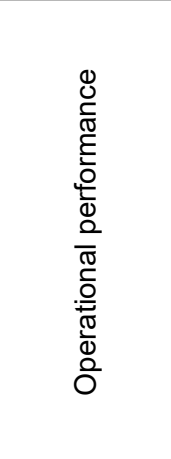 } & OPER01 & $\begin{array}{l}\text { We have implemented improvements in the } \\
\text { process that reduce production costs (Cost) }\end{array}$ & \multirow{5}{*}{$\begin{array}{c}\text { Adapted } \\
\text { from Ahmad } \\
\text { \& Schroeder } \\
\text { (2003) }\end{array}$} \\
\hline & OPER02 & $\begin{array}{l}\text { We have been able to manufacture our products } \\
\text { according to the specifications made in product } \\
\text { design (Quality) }\end{array}$ & \\
\hline & OPER03 & $\begin{array}{l}\text { We can deliver the goods to our customers within } \\
\text { the agreed timeframe (Reliability) }\end{array}$ & \\
\hline & OPER04 & $\begin{array}{l}\text { We can quickly change production volume and } \\
\text { variety of products to meet customer demand } \\
\text { (Flexibility) }\end{array}$ & \\
\hline & OPER05 & $\begin{array}{l}\text { We usually launch new products on the market } \\
\text { before our competitors (Speed) }\end{array}$ & \\
\hline
\end{tabular}

The population is composed of companies belonging to the textile industry. The choice of the textile industry to perform the research is due to the dynamics and market trends that force companies to launch a range of new products on a quarterly basis. Additionally, there is a lack of empirical studies dealing with the integration of the supply chain in this industry. The sample is non-probabilistic of transversal application. 
A link to fill out the survey was sent to directors and corporate managers. Product, marketing, production, customer relationship managers and suppliers were asked to complete the questionnaire together. Questionnaires were collected from 120 companies, however, after data processing, 112 companies remained in the database. These companies are medium-sized apparel manufacturers located in seven Brazilian states: Santa Catarina, Rio Grande do Sul, Paraná, Goiás, Espírito Santo, Minas Gerais and São Paulo. The dimensions were validated by means of confirmatory factorial analysis (CFA), privileging the questions with factorial loads higher than 0.7 and significant at the 0.05 level. The adjustment indexes of the dimensions were also analyzed through the CFI, GFI and RMSEA coefficients. The CFI (Comparative Fit Index) calculates the relative fit of the observed model when comparing it with a base model. RMSEA (Root-Mean-Square Error of Approximation) refers to the root mean square of the approximation errors. We also used goodness-of-fit (GFI), which measures variance and covariance in the observed matrix, predicted by the reproduced matrix. While the values of CFI and GFI should be greater than 0.90, the RMSEA coefficient should preferably be between 0.04 and 0.08 (Kline, 2015). The issues that do not meet the established parameters are excluded in order to increase the reliability of the dimensions. He failed to explain what stands for the acronyms $\mathrm{CFI}, \mathrm{GFI}$ and RMSEA, and give a brief explanation of its concept and application. After this procedure, we verified the degree of convergence of the issues in the dimensions that are allocated through composite reliability (CR) and analysis of the extracted variance (AVE). Coefficients greater than 0.7 and 0.5 for composite reliability and AVE, respectively, are desirable (Kline, 2015). The validation was performed on the latent variables that had an independent and reflexive character in the analyzes, such as the integration with the supplier and the adoption of Lean practices. The operational performance dimension, given its formative character, was not validated, since its indicators were used in the structural model individually. The discriminant validity between the independent variables was also performed. The discriminant validity was composed of two steps. In the first step the independent variables were linked by covariance and in the second stage the covariance was set at 1 . Finally, the chi-square difference between the two steps was calculated, which should be greater than 10,827 to guarantee a distinction between the variables at the level of 0.01 (Bagozzi \& Phillips, 1982; Stratman \& Roth, 2002).

Finally, the relation between the dimensions, according to Figure 1, was verified through the Structural Equations Modeling (SEM). In this analysis, relationships with $p$-value of less than 0.05 are considered significant. The results of the analyzes were presented in tables to facilitate the understanding.

\section{Data analysis}

Initially, we proceeded with the refinement and validation of the dimensions. For that, we used the confirmatory factorial analysis, observing the factor loads, significance and adjustment indexes. The initial validation data are presented in Table 2. 
Table 2. Initial data from validation of dimensions.

\begin{tabular}{|c|c|c|c|c|c|c|c|c|}
\hline Dimensions & Items & Loads & P-value & $\mathbf{R}^{2}$ & $\mathrm{x}^{2} / \mathrm{df}$ & $\mathrm{CFI}$ & GFI & RMSEA \\
\hline \multirow{6}{*}{$\begin{array}{c}\text { Supplier } \\
\text { integration }\end{array}$} & SUPP01 & 0.660 & ${ }^{* \star \star}$ & 0.44 & \multirow{6}{*}{3.330} & \multirow{6}{*}{0.894} & \multirow{6}{*}{0.902} & \multirow{6}{*}{0.161} \\
\hline & SUPP02 & 0.822 & $* * *$ & 0.68 & & & & \\
\hline & SUPP03 & 0.727 & $* * *$ & 0.53 & & & & \\
\hline & SUPP04 & 0.755 & $* * *$ & 0.57 & & & & \\
\hline & SUPP05 & 0.554 & $* * *$ & 0.31 & & & & \\
\hline & SUPP06 & 0.535 & $* * *$ & 0.29 & & & & \\
\hline \multirow{5}{*}{$\begin{array}{c}\text { Lean } \\
\text { Practices } \\
\text { adoption }\end{array}$} & LEAN01 & 0.629 & $* * *$ & 0.40 & \multirow{5}{*}{2.788} & \multirow{5}{*}{0.888} & \multirow{5}{*}{0.944} & \multirow{5}{*}{0.141} \\
\hline & LEAN02 & 0.573 & $* * *$ & 0.33 & & & & \\
\hline & LEAN03 & 0.830 & $* * *$ & 0.69 & & & & \\
\hline & LEAN04 & 0.294 & 0.017 & 0.09 & & & & \\
\hline & LEAN05 & 0.456 & $* * *$ & 0.21 & & & & \\
\hline
\end{tabular}

${ }^{* * *} \mathrm{p}$-value < 0.01; R2 - Coefficient of determination; $\mathrm{x} 2 / \mathrm{df}$ - chi-square statistic/Degree of freedom; CFI Comparative Fit Index; GFI - Goodness-of-fit; RMSEA - Root-Mean-Square Error of Approximation.

According to Table 2, three questions were highlighted due to the low factor loads. Other issues, although also below the value of 0.70 , were not withdrawn because they undermined the reliability of the dimensions. Thus, aiming at the best adjustment indices of the dimensions, only the issues highlighted in gray were excluded. The final data of the refinement of the dimensions are presented in Table 3.

Table 3. Final data from validation of dimensions.

\begin{tabular}{|c|c|c|c|c|c|c|c|c|}
\hline Dimensions & Items & Loads & P-value & $\mathbf{R}^{2}$ & $x^{2} / d f$ & CFI & GFI & RMSEA \\
\hline \multirow{4}{*}{$\begin{array}{c}\text { Supplier } \\
\text { integration }\end{array}$} & SUPP01 & 0.636 & $* * *$ & 0.40 & \multirow{4}{*}{2.732} & \multirow{4}{*}{0.975} & \multirow{4}{*}{0.969} & \multirow{4}{*}{0.08} \\
\hline & SUPP02 & 0.767 & $* * *$ & 0.59 & & & & \\
\hline & SUPP03 & 0.767 & $* * *$ & 0.59 & & & & \\
\hline & SUPP04 & 0.819 & $* * *$ & 0.67 & & & & \\
\hline \multirow{4}{*}{$\begin{array}{l}\text { Lean } \\
\text { Practices } \\
\text { adoption }\end{array}$} & LEAN01 & 0.670 & $* * *$ & 0.45 & \multirow{4}{*}{3.226} & \multirow{4}{*}{0.938} & \multirow{4}{*}{0.947} & \multirow{4}{*}{0.07} \\
\hline & LEAN02 & 0.640 & $* * *$ & 0.41 & & & & \\
\hline & LEAN03 & 0.861 & $* * *$ & 0.74 & & & & \\
\hline & LEAN05 & 0.630 & $* * *$ & 0.40 & & & & \\
\hline
\end{tabular}

${ }^{* * *}$-value $<0.01 ; \mathrm{R} 2$ - Coefficient of determination; $x 2 / \mathrm{df}$ - chi-square statistic/Degree of freedom; CFI Comparative Fit Index; GFI - Goodness-of-fit; RMSEA - Root-Mean-Square Error of Approximation.

According to Table 3, after the exclusion of the questions, there was an increase in the adjustment indices of the dimensions that indicate convergence with the parameters stipulated in the literature. The composite reliability and variance extracted from the dimensions were calculated to guarantee the internal convergence of the dimensions. The results obtained indicate acceptable degrees of composite reliability (CR) and extracted variance (AVE) for both dimensions, according to Table 4.

Table 4. Internal convergence of dimensions.

\begin{tabular}{ccc}
\hline Dimension & CR & AVE \\
\hline Supplier integration & 0.84 & 0.56 \\
\hline
\end{tabular}




\begin{tabular}{ccc}
\hline Dimension & CR & AVE \\
\hline Lean practices adoption & 0.80 & 0.50 \\
\hline
\end{tabular}

CR - Composite Reliability; AVE - Average Variance Extracted.

Thus, it was possible to verify the discriminant validity between dimensions, and then test structural model. The discriminant validity, as described in the methodology was done in two steps. First, the variables were connected by covariance and the chisquare was calculated. Subsequently, a degree of freedom was added to covariance, set to 1 , and a new chi-square was calculated. The difference between chi-squares when greater than 10,827 gives discriminant validity to the variables at the 0.01 level. The result of the discriminant validity is shown in Table 5.

Table 5. Discriminant Validity.

\begin{tabular}{ccccccc}
\hline \multirow{2}{*}{ Dimensions in pairs } & \multicolumn{2}{c}{ No restriction } & \multicolumn{2}{c}{ With restriction } & \multirow{2}{*}{${ }^{*} \mathbf{X}^{2}$} \\
\cline { 3 - 6 } & $\mathbf{X}^{2}$ & $\mathbf{d f}$ & $\mathbf{X}^{2}$ & $\mathbf{d f}$ & Difference \\
\hline $\begin{array}{c}\text { Supplier } \\
\text { integration }\end{array}$ & $\begin{array}{c}\text { Lean Practices' } \\
\text { adoption }\end{array}$ & 46.751 & 16 & 73.664 & 20 & 26.913 \\
\hline
\end{tabular}

$\mathrm{X} 2$ - chi-square statistic; $\mathrm{df}=-$ Degree of freedom; * $\mathrm{p}$-value $<0.05$.

After this procedure, the relationships proposed in Figure 1 were tested through the Structural Equations Modelling. Operational performance indicators were analyzed individually, as dependent variables, in the structural model. The results of this analysis are presented in Table 6.

Table 6. Structural Model Test.

\begin{tabular}{|c|c|c|c|c|}
\hline Independent variable & $\begin{array}{c}\text { Dependent } \\
\text { variable }\end{array}$ & Coefficient & p-value & $\mathbf{R}^{2}$ \\
\hline \multirow{2}{*}{ Supplier integration } & Lean Practices & 0.086 & 0.498 & 0.007 \\
\hline & Cost & 0.040 & 0.580 & \multirow{2}{*}{0.399} \\
\hline Lean Practices & Cost & 0.625 & $* * *$ & \\
\hline \multirow{2}{*}{ Supplier integration } & Lean Practices & 0.160 & 0.228 & 0.026 \\
\hline & Quality & 0.186 & 0.095 & \multirow{2}{*}{0.165} \\
\hline Lean Practices & Quality & 0.333 & 0.007 & \\
\hline \multirow{2}{*}{ Supplier integration } & Lean Practices & 0.146 & 0.268 & 0.021 \\
\hline & Delivery & 0.039 & 0.732 & \multirow{2}{*}{0.025} \\
\hline Lean Practices & Delivery & 0.149 & 0.221 & \\
\hline \multirow{2}{*}{ Supplier integration } & Lean Practices & 0.131 & 0.315 & 0.017 \\
\hline & Flexibility & 0.066 & 0.558 & \multirow{2}{*}{0.079} \\
\hline Lean Practices & Flexibility & 0.264 & 0.031 & \\
\hline \multirow{2}{*}{ Supplier integration } & Lean Practices & 0.192 & 0.153 & 0.037 \\
\hline & Speed & 0.322 & 0.005 & \multirow{2}{*}{0.197} \\
\hline Lean Practices & Speed & 0.251 & 0.034 & \\
\hline
\end{tabular}

$\mathrm{R}^{2}$ - Coefficient of determination. 


\section{Discussion of results}

According to Table 6 , cost performance is influenced by 0.625 by the adoption of lean practices, not influenced by supplier integration in the development of new products. This finding is in line with previous studies on the adoption of lean practices that eliminate production waste and maximize resources, which consequently increase cost efficiency (Belekoukias et al., 2014; Inman \& Green, 2018).

On the other hand, the non-influence of the suppliers in the cost performance reaffirms the results from Flynn et al. (2010) and Thomé et al. (2014a), in which the practice of supply chain integration did not have a significant impact on operational performance. On the other hand, the results do not corroborate with the findings of Monczka et al. (1993), who identified better cost performance after integration. It is also verified that in the cost analysis model, integration with suppliers does not favor the adoption of lean practices. On the other hand, the results go against the studies of Monczka et al. (1993), who identified better cost performance after integration. It is also verified that in the cost analysis model, integration with suppliers does not favor the adoption of lean practices.

Similarly, performance in quality is direct and significantly influenced by the adoption of lean practices, which by their nature includes management practices related to quality systems (Shah \& Ward, 2003; Belekoukias et al., 2014; Inman \& Green, 2018). However, it does not suffer significant influence from supplier integration (Thomé et al., 2014a). In this way, this result is supported by previous research that found the same relationships (Swink et al., 2007; Flynn et al., 2010). The results of this research contrast the findings of previous research that tested the relationship between supplier integration and quality in different industries and found positive and significant evidence for this (Petersen et al., 2005). In terms of reliability, no significant relationships were found between any variables of the structural model. In other words, integration with supplier does not favor the adoption of lean practices, which in turn does not influence reliability. This result contradicts Belekoukias et al. (2014) arguments' that proximity to suppliers is one of the characteristics of lean that helps organizations improve reliability. Also, no direct and significant relationships between supplier integration and reliability were found. One possible explanation is related to the characteristics of the textile companies, marked by the dynamics of the market in which they are inserted and of fashion trends. Also, no direct and significant relationships between supplier integration and reliability were found. One possible explanation is related to the characteristics of the textile companies, marked by the dynamics of the market in which they are inserted and of trends.

The adoption of lean practices also has a significant relationship with flexibility. As in reliability performance, flexibility is intrinsic to the nature of the textile industry, once every three months new collections of products are launched, awakening in companies the need to adapt their resources to produce according to the trends of Marketplace. The adoption of lean practices based on lean systems increases the adaptability of companies by providing product flexibility, production volume and lead times. The proximity of suppliers is one of the characteristics of lean that helps organizations improve reliability (Belekoukias et al., 2014). Finally, speed was analyzed as an indicator of operational performance. For this indicator the integration with supplier has greater influence when compared to the adoption of lean practices. In the case of the industry under study, the supplier is responsible for supplying materials or components to produce products, as well as offering alternative technologies that minimize production time, increase productivity and shorten the time to launch new products. 
Although with less influence, the adoption of lean practices, by eliminating the wastes of the productive process, make the flow of production more fluid, increasing the speed of attendance to the needs of the clients.

It is also observed that the integration of the supplier does not favor the adoption of lean practices in any of the models tested. Based on this result, it is argued that the incorporation of the lean philosophy in the context of the companies is elucidated from the production challenges and the intention to obtain better operational performance, according to the results found by Khanchanapong et al. (2014). Because it is an organizational goal, focused on internal efficiency, it is believed that integration with the supplier in the performance of new products does not exert a significant influence on the adoption of these practices. In general, the results of this research corroborate the conclusions of Handfield et al. (1999), noting that many companies perceive the importance of supplier integration but have not yet figured out how to achieve it successfully to obtain better operational results

\section{Final considerations}

This study aimed to evaluate the influence of supplier integration and the adoption of lean practices on the operational performance of the new product development process. The study was carried out with medium-sized companies of the textile industry due to the dynamics of the market in which these companies are inserted.

In general, it has been found that supplier integration has a positive and significant influence only on the speed of introduction of new products, since they provide alternative technologies that facilitate the production process and decrease the product launch time. The adoption of lean practices was significant for the operational performances tested, except for reliability. The implementation of the lean philosophy was better evidenced in cost performance, where waste elimination, increased resource optimization and consequent productivity, increase operational efficiency by reducing costs.

The study contributes theoretically through the verification of the influence of supplier integration and the adoption of lean practices in operational performance, complementing the existing knowledge in this area from a new perspective: low-tech industries, but with a continuous flow of product development, already that existing studies are focused on rapidly changing industries such as automotive, electronics and machinery. In practical terms, managers of organizations in the same industry can gain insight into investments in areas that can bring potential benefits such as the adoption of lean philosophy and the expected results from them.

The limitation of this study lies in the intrinsic subjectivity of research using psychometric scales. It is suggested, therefore, the development of measurement scales for the studied dimensions based on the observation of implementation of practices of both supplier integration and adoption of the lean philosophy, as well as the intensity in which they occur.

As a suggestion for future research, it is hoped to expand this study to elucidate dimensions that act as determinants of the adoption of lean practices and that can significantly influence the operational performance of low-tech companies, but short and fast cycle products obsolescence. 


\section{References}

Ahmad, S., \& Schroeder, R. G. (2003). The impact of human resource management practices on operational performance: recognizing country and industry differences. Journal of Operations Management, 21(1), 19-43. http://dx.doi.org/10.1016/S0272-6963(02)00056-6.

Armistead, C., \& Mapes, J. (1993). The impact of supply chain integration on operating performance. Logistics Information Management, 6(4), 9-14. http://dx.doi.org/10.1108/09576059310045907.

Bagozzi, R. P., \& Phillips, L. W. (1982). Representing and testing organizational theories: a holistic construal. Administrative Science Quarterly, 27(3), 459-489. http://dx.doi.org/10.2307/2392322.

Belekoukias, I., Garza-Reyes, J. A., \& Kumar, V. (2014). The impact of lean methods and tools on the operational performance of manufacturing organizations. International Journal of Production Research, 52(18), 5346-5366. http://dx.doi.org/10.1080/00207543.2014.903348.

Bhamu, J., \& Singh Sangwan, K. (2014). Lean manufacturing: literature review and research issues. International Journal of Operations \& Production Management, 34(7), 876-940. http://dx.doi.org/10.1108/IJOPM-08-2012-0315.

Brown, S. L., \& Eisenhardt, K. M. (1995). Product development: past research, present findings, and future directions. Academy of Management Review, 20(2), 343-378. http://dx.doi.org/10.5465/amr.1995.9507312922.

Chen, I. J., \& Paulraj, A. (2004). Towards a theory of supply chain management: the constructs and measurements. Journal of Operations Management, 22(2), 119-150. http://dx.doi.org/10.1016/j.jom.2003.12.007.

Cooper, R. G., \& Kleinschmidt, E. J. (1986). An investigation into the new product process: steps, deficiencies and impact. Journal of Product Innovation Management, 3(2), 71-85. http://dx.doi.org/10.1111/1540-5885.320071.

De Toni, A., \& Nassimbeni, G. (2000). Just-in-time purchasing: an empirical study of operational practices, supplier development and performance. Omega, 28(6), 631-651. http://dx.doi.org/10.1016/S0305-0483(00)00016-5.

Devaraj, S., Krajewski, L., \& Wei, J. C. (2007). Impact of eBusiness technologies on operational performance: the role of production information integration in the supply chain. Journal of Operations Management, 25(6), 1199-1216. http://dx.doi.org/10.1016/j.jom.2007.01.002.

Dyer, J. H. (1996). Specialized supplier networks as a source of competitive advantage: evidence from the auto industry. Strategic Management Journal, 17(4), 271-291. http://dx.doi.org/10.1002/(SICI)1097-0266(199604)17:4<271::AID-SMJ807>3.0.CO;2-Y.

Feng, M., Yu, W., Wang, X., Wong, C. Y., Xu, M., \& Xiao, Z. (2018). Green supply chain management and financial performance: the mediating roles of operational and environmental performance. Business Strategy and the Environment, 27(7), 811-824. http://dx.doi.org/10.1002/bse.2033.

Flynn, B. B., Huo, B., \& Zhao, X. (2010). The impact of supply chain integration on performance: a contingency and configuration approach. Journal of Operations Management, 28(1), 58-71. http://dx.doi.org/10.1016/j.jom.2009.06.001.

Handfield, R. B., Ragatz, G. L., Petersen, K. J., \& Monczka, R. M. (1999). Involving suppliers in new product development. California Management Review, 42(1), 59-82. http://dx.doi.org/10.2307/41166019.

Hopp, W. J., \& Spearman, M. L. (2004). To pull or not to pull: what is the question? Manufacturing \& Service Operations Management : M \& SOM, 6(2), 133-148. http://dx.doi.org/10.1287/msom.1030.0028. 
Inman, R. A., \& Green, K. W. (2018). Lean and green combine to impact environmental and operational performance. International Journal of Production Research, 56(14), 1-17. http://dx.doi.org/10.1080/00207543.2018.1447705.

Jasti, N. V. K., \& Kodali, R. (2015). Lean production: literature review and trends. International Journal of Production Research, 53(3), 867-885. http://dx.doi.org/10.1080/00207543.2014.937508.

Khanchanapong, T., Prajogo, D., Sohal, A. S., Cooper, B. K., Yeung, A. C., \& Cheng, T. C. E. (2014). The unique and complementary effects of manufacturing technologies and lean practices on manufacturing operational performance. International Journal of Production Economics, 153, 191-203. http://dx.doi.org/10.1016/j.jpe.2014.02.021.

Kline, R. B. (2015). Principles and practice of structural equation modeling. New York: Guilford Publications.

Krishnan, V., \& Ulrich, K. T. (2001). Product development decisions: a review of the literature. Management Science, 47(1), 1-21. http://dx.doi.org/10.1287/mnsc.47.1.1.10668.

Li, S., Rao, S. S., Ragu-Nathan, T. S., \& Ragu-Nathan, B. (2005). Development and validation of a measurement instrument for studying supply chain management practices. Journal of Operations Management, 23(6), 618-641. http://dx.doi.org/10.1016/j.jom.2005.01.002.

Liker, J. K., \& Meier, D. (2007). O modelo Toyota-manual de aplicação: um guia prático para a implementação dos 4Ps da Toyota. Porto Alegre: Bookman.

Liker, J. K., \& Morgan, J. M. (2006). The Toyota way in services: the case of lean product development. The Academy of Management Perspectives, 20(2), 5-20. http://dx.doi.org/10.5465/amp.2006.20591002.

Monczka, R. M., Trent, R. J., \& Callahan, T. J. (1993). Supply base strategies to maximize supplier performance. International Journal of Physical Distribution \& Logistics Management, 23(4), 42-54. http://dx.doi.org/10.1108/09600039310041509.

Pérez, M. P., \& Sánchez, A. M. (2000). Lean production and supplier relations: a survey of practices in the Aragonese automotive industry. Technovation, 20(12), 665-676. http://dx.doi.org/10.1016/S0166-4972(00)00011-0.

Petersen, K. J., Handfield, R. B., \& Ragatz, G. L. (2005). Supplier integration into new product development: coordinating product, process and supply chain design. Journal of Operations Management, 23(3-4), 371-388. http://dx.doi.org/10.1016/j.jom.2004.07.009.

Rahman, S., Laosirihongthong, T., \& Sohal, A. S. (2010). Impact of lean strategy on operational performance: a study of Thai manufacturing companies. Journal of Manufacturing Technology Management, 21(7), 839-852. http://dx.doi.org/10.1108/17410381011077946.

Shah, R., \& Ward, P. T. (2003). Lean manufacturing: context, practice bundles, and performance. Journal of Operations Management, 21(2), 129-149. http://dx.doi.org/10.1016/S0272-6963(02)00108-0.

Stratman, J. K., \& Roth, A. V. (2002). Enterprise resource planning (ERP) competence constructs: two-stage multi-item scale development and validation. Decision Sciences, 33(4), 601-628. http://dx.doi.org/10.1111/j.1540-5915.2002.tb01658.x.

Swink, M., Narasimhan, R., \& Wang, C. (2007). Managing beyond the factory walls: effects of four types of strategic integration on manufacturing plant performance. Journal of Operations Management, 25(1), 148-164. http://dx.doi.org/10.1016/j.jom.2006.02.006.

Thomé, A. M. T., Sousa, R. S., \& Scavarda do Carmo, L. F. R. R. (2014a). The impact of sales and operations planning practices on manufacturing operational performance. International Journal of Production Research, 52(7), 2108-2121. http://dx.doi.org/10.1080/00207543.2013.853889.

Thomé, A. M. T., Sousa, R. S., \& Scavarda do Carmo, L. F. R. R. (2014b). Complexity as contingency in sales and operations planning. Industrial Management \& Data Systems, 114(5), 678-695. http://dx.doi.org/10.1108/IMDS-10-2013-0448. 
Watts, C. A., \& Hahn, C. K. (1993). Supplier development programs: an empirical analysis. International Journal of Purchasing and Materials Management, 29(1), 10-17. http://dx.doi.org/10.1111/j.1745-493X.1993.tb00002.x.

Womack, J. P., Jones, D. T., \& Roos, D. (1990). Machine that changed the world. New York: Simon and Schuster. 